\title{
Bulb Mites Rhizoglyphus echinopus (Fumouze and Robin) Associated with Subterranean Termite (Isoptera) in Brazil
}

\author{
Ademar Ferreira Silva ${ }^{1 *}$, Zeneida Teixeira Pinto ${ }^{\circledR * *}$, Rebecca Leal Caetano ${ }^{1^{*}}$ \\ César Carriço $^{1 *}$, Tayra Pereira Sato ${ }^{1 *}$, Marinete Amorim ${ }^{1 *}$ \& Gilberto Salles Gazeta ${ }^{*}$
}

1. Instituto Oswaldo Cruz - FIOCRUZ, e-mail: afsademar@gmail.com, zeneidateixeirapinto@gmail.com (Autor para correspondência ${ }^{\bowtie}$ ), rebeccalealcaetano@gmail.com, carric082@hotmail.com, satotayra@yahoo.com.br, mamorim@ioc.fiocruz.br, gsgazeta@gmail.com.

*Laboratório de Referência Nacional em Vetores das Riquetsioses (LIRN). *** Laboratório de Educação em Ambiente e Saúde - LEAS. * Programa de Pós-Graduação em Biodiversidade e Saúde.

\section{EntomoBrasilis 9 (1): 65-68 (2016)}

Abstract. Four bulb mites deutonymphs (hypopus) from Rhizoglyphus echinopus (Fumouze \& Robin) (Acari: Acaridae) were found attached to the head of a subterranean termite belonging to Coptotermes genus in Rio de Janeiro, Brazil. These mite species are commonly associated with ornamental plants and trees with bulbs, corms and tubers. All four hypopus were found attached to the surface of termite's head. Results from this study provided an insight on the phoretic relationship of mites and termites, indicating the role of the latter in the dispersion of the first.

Keywords: Acaridae; Arthropods; Dispersion; First record; Phoresy.

\section{Ácaros do Bulbo Rhizoglyphus echinopus (Fumouze and Robin) Associados com Cupim Subterrâneo (Isoptera) no Brasil}

Resumo. Quatro deutoninfas de ácaros do bulbo (hipopus) da espécie Rhizoglyphus echinopus (Fumouze \& Robin) (Acari: Acaridae) foram encontradas fixadas na cabeça do cupim subterraneo pertencente ao gênero Coptotermes no Rio de Janeiro, Brasil. Estas espécies de ácaros estão comumente associadas a plantas ornamentais e plantas com bulbos e turbéculos. As quatros hipopus foram encontradas fixadas na superfície da cabeça do cupim. Os resultados desse estudo fornecem uma visão sobre a relação forética de ácaros e cupins, indicando o papel deste último na dispersão do primeiro.

Palavras-chave: Acaridae; Artrópodes; Dispersão; Forésia; Primeiro registro.

T[ ermites are social insects that live housed in nests called mounds or termites mounds (LARA 1992). According to VASCONCELlos et al. (2005), they can modify the soil structure, influencing the availability of food sources for other organisms. Termite mounds are made to house colonies; it is a micro - particular habitat, attracting a great variety of organisms, including worms, arthropods and vertebrates (SANTOS et al. 2007).

Rhinotermitidae family is widely distributed in tropical, subtropical and temperate regions (EGGLETON 2000). This family has as main characteristic: a fontanelle and a frontal gland in the imago and soldier castes (ChatterJee \& Thakur 1964; Emerson 1965). The latter may vary according to genus (Šовотмі́к et al. 2010).

The genus Coptotermes belong to the Rhinotermitidae family and comprises 71 described species (VARGO \& HUSSENEDER 2009). Most of these species were introduced by man and occur in all tropical and subtropical regions (Constantino 1999), being adapted to all major biomes and inhabiting the heartwood of living trees, or underground (Bourguignon \& RoIsin, 2011). Several species of Coptotermes genus are major pests of buildings (Su \& SCHEFFRAHN 2000).

Some invertebrates can accidentally enter the termites mound, others definitely keep a relationship of society with termites (BARRETO \& CASTRO 2007). Thus, different authors have reported the occurrence of ants (SANTOS et al. 2007), mites, spiders, beetles and caterpillars (e.g. CunHa et al. 2003; CARvalHo 2005) but, the most numerous were mites (Acari) (EICKWORT 1990).

According to Costa-LEONARdo \& SOARES (1993), mites are usually found in termites colonies. Some mites are accidental, whereas others are related them by necessity (SAMsINÁK 1964); these mites are saprophytes and phoretic (WANG et al. 2002).

Mites may be found worldwide and has radiated into many habitats. They are, mainly, phytophagous, micophagous, saprophagic and parasites, which can be seen in various hosts, as well as in stored products, homes, nests and various types of soils and waste (Phillips 1990). OC'ONNOR (1994) reported that this group is specialized in exploring temporary and restricted environments.

These individuals are known to be good indicators of environmental impact and acid rain, in addition to agrochemical residues and some effects of agricultural practices (PAOLETTI et al. 1991). These mites can accumulate heavy metals in their bodies, making them an important tool as indicators of disturbed sites (STRAALEN 1996) and deutonynphs are typical insect phoretics.

Rhizoglyphus echinopus (Fumouze \& Robin) (Acari: Oribatida) inhabit bulbs and other root crops, This kind of mite is widely

Funding Agencies: Conselho Nacional de Desenvolvimento Científico e Tecnológico (CNPq), Coordenação de Aperfeiçoamento de Pessoal de Nível Superior (CAPES) and Fundação Oswaldo Cruz . 
distributed throughout the world. This species is capable of causing injuries on plant tissue, facilitating the entry of pest organisms and pathogens through the damages (Diaz et al. 2000; Estrada-Venegas 2003; FAn \& Zang 2004). According Phillipsen \& Coppel (1977), a few mites feed on termites. The species Acotyledon formosani Phillipsen \& Coppel (Acarina: Acaridae), in association with the genus Australhypopus (Acaridae) can cause death in weak colonies of termites. WANG et al. (2002), studying the colony of termites, showed that the fauna of mites associated with them is quite different and mites were found mainly in the termite's head and on the thorax, abdomen and legs.

Our study is the first record of association between the mite R. echinopus and the Coptotermes termite in Brazil.

Mites were collected attached to the head of a termite from Cascadura (22.88.2'62,7”S, 43.33,8'59"W), RJ/ Brazil. The place of collection is plentiful of fruit trees and ornamental plants.

Termite was properly identified by dicotomic keys from Constantino (1999) and Tripplehorn \& Johnson (2004), and checked out for the presence of phoretic mites.

Mites were mounted between slide and coverslip in Hoyer's media as preservative (FLECHTMANN 1975) and examined under optical light microscopy. The specimens were properly identified following Flechtmann (1975), Krantz \& WaLter (2009) and FAN \& ZHANG (2004).

Specimens were deposited with these vouchers (CAVAISC-ACA 179a and CAVAISC-ACA-179b) at Coleção de Artrópodes Vetores Ápteros de Importância em Saúde das Comunidades (CAVAISC) of Laboratório de Referência Nacional em Vetores das Riquetsioses (LIRN), Instituto Oswaldo Cruz, Fundação Oswaldo Cruz (IOC/ FIOCRUZ), 10. Xii. 2014, head. A. F. Silva (Figure 1). Hypopus were amplified at $100 \mathrm{X}$ taken photomicrographs with a camera coupled to a digital microscope Zeizz $\AA$.

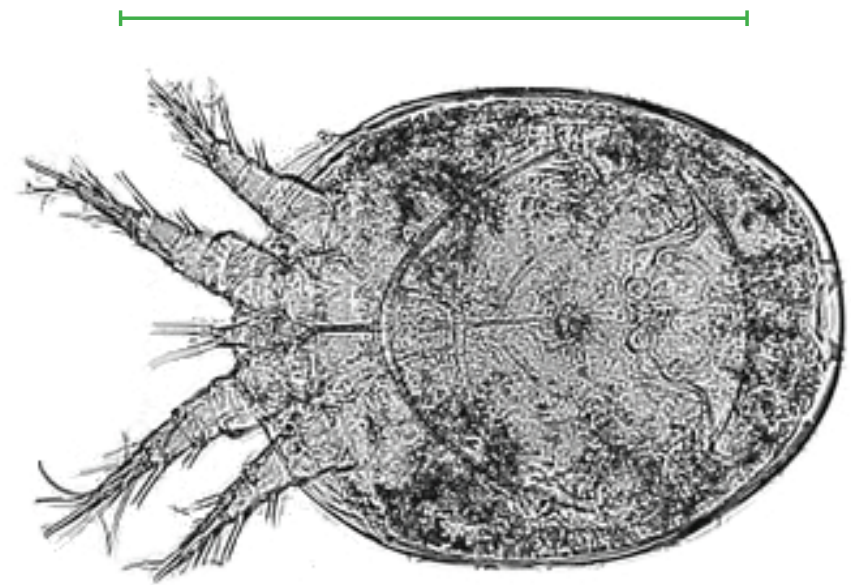

Figure 1: Deutonymph (hypopus) of Rhizoglyphus echinopus (Fumouze and Robin) (Acari: Acaridae). 100X (picture by Pinto, ZT).

The identified termite belongs to the subterranean genus Coptotermes. This genus constitutes one of the most widespread termites, including numerous pest species (Constantino 1999; BOURGUIGNON \& RoISIN 2011).

Rhizoglyphus deutonymphs have been observed associated in many beetles, like: Osmoderma eremicola (Knoch), Bothynus gibbosus (De Geer), and Phyllophaga anxia LeConte; Geotrupes stercorosus (Linnaeus) and Stenochetus gravis (Fabricius) (Norton 1973; Rogers 1974; De \& Pande 1988; Poprawski \& Yule 1992; Marakova 1995), as well as in some Diptera (Garman 1937; ZaKhVATKIn 1941) and Siphonaptera (FAIN \& Beaucournu 1993). WANG et al. (2002) observed a opportunistic or phoretic relationship between different species of mites and three subterranean termite species.

Some organism associated with termites can behave as parasitic, mutualistic, phoretic, predatory or commensal (WANG et al. 2002). Four deutonymphs of $R$. echinopus mite species were associated with Coptotermes specimens. All mites were found attached to their host head and according to Phillipsen \& Coppel (1977), the presence of mites in the head and mouthparts of termites make normal feeding behavior difficult. The abundance of mites can also prejudice the sexual behavior of the phoront (RoDRIGUEs et al. 2013).

According to EL-ERAKY et al. (2015), most mite species associated with termites were considered as saprophagous or phoretic. These associations have been reported by many authors (KRANTZ 2001; Myles 2002a, 2002b; SCHARF et al. 2002; WANG et al. 2002; KORB \& FUCKS 2006).

The heteromorphic deutonynph known as hypopus is a facultative stage present in Astigmatina. This stage is highly resistant to environmental stresses, and commonly have body highly sclerotised, dorsoventrally flat, gnathosoma reduced, chelicerae absent and ventral suckers or claspers with which they secure attachmrnt to passing animals (FAN \& ZHANG 2004; KRANTZ \& WALTER 2009).

According to WALTER \& PROCTOR (1999) phoresy is simply a form of temporary symbiosis in wich a smaller individual is transported on a larger individual, irrespective of feeding or other activity. Based on the Walter-Proctor definition and the observations above the relationship between the Coptotermes termite and the mite $R$. echinopus is characterized as a phoretic association.

Reports on this association are still very sparse and need to be further clarified.

\section{ACKNOWLEDGMENT}

We are very thankful to The Mycological Collection Trichocomaceae (FIOCRUZ - IOC), facilitated the use of microscopical image capture (Mário Gatti and Rodolfo Armando da Cunha) and Paulo Vander Ferreira Santana for his help with the article English revision. We would like to thank Conselho Nacional de Desenvolvimento Científico e Tecnológico (CNPq), Coordenação de Aperfeiçoamento de Pessoal de Nível Superior (CAPES) and Fundação Oswaldo Cruz for the grants and fellowships provided.

\section{REFERENCES}

Barretos, L.S. \& M.S. Castro, 2007. Ecologia de nidificação de abelhas do gênero Partamona (Hymenoptera: Apidae) na caatinga, Milagres, Bahia. Biota Neotropica, 7: 87-92. DOI: http://dx.doi.org/10.1590/S1676-06032007000100012.

Bourguignon T. \& Y. Roisin, 2011. Revision of the termite family Rhinotermitidae (Isoptera) in New Guinea. Zookeys, 148: 55103. DOI: http://dx.doi.org/10.3897/zookeys.148.1826.

Carvalho, R.A. \& D. Brandão, 2005. Estudo sobre a fauna de invertebrados associada a ninhos de Cornitermes cumulans (Kollar) no Parque Estadua das Emas, Mineiros, Goiás. Dissertação (Mestrado em Biologia) - Universidade Federal de Goiás. 86 p.

Chatterjee, P.N. \& M.L. Thakur, 1964. Sarvaritermes faveolus gen. et sp. nov. from Kulu Valley (Punjab: India) [Isoptera], with a discussion on the systematic position and relationship of the family Stylotermitidae. Zoologischer Anzeiger, 173: 149-162.

Constantino, R., 1999. Chave ilustrada para identificação dos gêneros de cupins (Insecta: Isoptera) que ocorrem no Brasil. Pápeis Avulsos de Zoologia, 40: 387-448. 
Costa-Leonardo, A.M. \& H.X. Soares, 1993. Occurrence of phoretic mites on the subterranean termite Heterotermes tenuis (Isoptera: Rhinotermitidae). Sociobiology, 23: 63-69.

Cunha, H.F., D.A. Costa, K.E.S. Filho, L.O. Silva \& D. Brandão, 2003. Relationship between Constrictotermes cyphergaster and Inquiline Térmites in the Cerrado (Isoptera: Termitidae). Sociobiology, 42: 1-10.

De, K. \& Y.D. Pande, 1988. Bionomics and some behavioral aspects of the mango stone weevil, Sternochetus gravis Fabricius (Coleoptera: Curculionidae). Entomon. 13: 17-24.

Díaz, A., Okabe, K., Eckenrode, C.J., Villani, M.G. \& B.M. Oconnor, 2000. Biology, ecology, and management of the bulb mites of the genus Rhizoglyphus (Acari: Acaridae). Experimental and Applied of Acarology, 24: 85-113. DOI: http://dx.doi.org/10.1023/A:1006304300657.

Eggleton, P., 2000. Global patterns of termite diversity, p 2551. In: Abe T., D.E. Bignell \& M. Higashi (Eds), Termites: Evolution, Sociality, Symbioses, Ecology. Kluwer Academic Publishers, Dordrecht, $467 \mathrm{p}$.

Eickwort, G.C., 1990. Associations of mites with social insects. Annual Review of Entomolology 35: 469-488. DOI: http://dx.doi.org/10.1146/annurev.en.35.010190.002345.

El-Eraky, E.A.M., S.S.D. Abb El-Aleem, M. Fakeer \& M.A.I Ahmed, 2015. First Record of two Mite species associated with subterranean termites in the New Valley Governorate, Egypty. The Journal of Biological Chemistry, 32: 227-289.

Emerson, A. E., 1965. A review of the Mastotermitidae (Isoptera) including a new fossil genus from Brazil. American Museum Novitates, 2236: 1-46.

Estrada-Venegas, E.G., 2003. El género Rhizoglyphus su importancia agrícola y como ácaro del suelo, p. 102-107. In: Romero-Nápoles, J., E.G. Estrada-Venegas \& A. EquihuaMartínez. (Eds.). Entomología Mexicana Vol. 2. Sociedad Mexicana de Entomología.

Fain, A. \& J.C. Beaucournu, 1993. Les hypopes des astigmates (Acari) phoretiques sur les puces (Siphonaptera) des mammiferes et d'oiseaux. Bulletin de Institut Royal des Sciences Naturalles de Belgique Entomologie, 63: 77-93.

Fan, Q.H. \& Z.Q. Zhang, 2004, Revision of Rhizoglyphus Claparède (Acari: Acaridae) of Australasia and Oceania. Systematic \& Applied Acarology Society. 374 p.

Flechtmann, C.H.H., 1975. Elementos de Acarologia. São Paulo, Livraria Nobel S.A., 344 p.

Garman, P., 1937. Astudy of the bulb mite (Rhizoglyphus hyacinthi Banks). Bulletin Connecticut Agricultural Experiment Station, 402: 889-907.

Korb, J. \& A. Fuchs, 2006. Termites and mites - adaptive behavioural responses to infestation. Behaviour, 143: 891907. DOI: http://dx.doi.org/10.1163/156853906778017917.

Krantz, G.W. \& D.E. Walter (Eds.), 2009. A Manual of Acarology 3rd Edition - Texas Tech University Press, 807 p.

Krantz, G.W., 2001. Two new species of the genus Haelaptonyssus Womersley from North America and Australia, with observations supporting the reinstatement to family level of the subfamily Laelaplonyssinae sensu Lee, 1970 Acari: Mesostigmata: Rhodacaroidea. Acarologia, 41: 25-38.

Lara, F.M., 1992. Princípios de Entomologia. $3^{\text {a }}$ Edição. São Paulo, Editora Cone, $331 \mathrm{p}$

Marakova, O.L, 1995. Mesostigmatid mites (Parasitiformes, Mesostigmata) on the forest dung beetle Geotrupes stercorosus. Zoologicheskii zhurnal, 74: 16-23.

Myles, T.G, 2002a. Observations on mites Acari associated with the eastern subterranean termite, Reticulitermes flavipes Isoptera: Rhinotermitidae. Sociobiology, 40: 277-280.

Myles, T.G, 2002b. Review of termite biocontrol agents with methods of isolation and culture, and dosing of the fungal pathogen, Metarhizium amsoplia. Sociobiology, 40: 281285 .

Norton, R.A, 1973. Phoretic mites associated with the hermit flower beetle Osmoderma eremicola Knoch (Coleoptera:
Scarabaeidae). The American midland naturalist, 90: 447449.

OC'onnor, B. M, 1994. Life history modifications in Astigmatid mites ed. Houck, Chapman \& Hall, New York, London, 6: 136-159p.

Paoletti, G.M, M. Favretto, B. Stinner, F. Purrington \& Bater J, 1991. Invertebrates as bioindicators of soil use. Agriculture, Ecosystems and Environment. 34: 341-362. DOI: http://dx.doi.org/10.1016/0167-8809(91)90120-M.

Phillips, J.R., 1990. Acarina: Astigmata (Acaridida), p. 757-778. In: Dindal, D.L. (ed) Soil Biology Guide, John Wiley and Sons, $1349 \mathrm{p}$.

Phillipsen, W. J. \& H.C. Coppel, 1977. Acotyledon formosani sp. n. associated with the Formosan subterranean termite, Coptotermes formosanus Shiraki (Acarina: AcaridaeIsoptera: Rhinotermitidae). Journal of the Kansas Entomological Society, 50: 399-409.

Poprawski, T.J. \& W.N. Yule, 1992. Acari associated with Phyllophaga anxia Leconte (Coleoptera:Scarabaeidae) in southern Quebec and eastern Ontario. The Canadian Entomologist, 124:397-403.DOI:http://dx.doi.org/10.4039/ Ent124397-2.

Rodrigues, M.E., C. Carriço, Z.T. Pinto, P.M. Mendonça \& M.M.C. Queiroz, 2013. First record of acari Arrenurus Dugès, 1834 as a parasite of Odonata species in Brazil. Biota Neotropical, 13: 365 - 367. DOI: http://dx.doi.org/10.1590/S167606032013000400029 .

Rogers, C.E., 1974. Bionomics of the carrot beetle in Texas rolling plains. Environmental Entomology, 3: 969-974.

Samsinák, K., 1964. Termitophile Milben aus der VR China. I. Mesostigmata. Entomologische Abhandlungen Museum für Tierkunde Dresden, 32: 33-52.

Santos, P.P., A. Vasconcellos \& J.H.C. Delabie, 2007. Uso de ninhos de Nasutitermes spp. (Isoptera; Termitidae) por formigas (Hymenoptera; Formicidae) na Bahia. Biológico, 69: $365-367$.

Scharf, M.E., E.A. Buss, C.R. Ratliff, D.J. Bard \& G.W. Bennet, 2002. Invertebrate taxa associated with subterranean termite monitoring devices in the Eastern Midwest. Sociobiology, 39: 441-451.

Šobotník, J., T. Bourguignon, R. Hanus, D. Sillam-Dusses, J. Pflegerová, F. Weyda, K. Kutalová, B. Vytisková \& Y. Roisin, 2010. Notonly soldiers haveweapons: evolution of thefrontal gland in imagoes of the termite families Rhinotermitidae and Serritermitidae. PLoS ONE 5: 15761-15768. DOI: http://dx.doi.org/10.1371/journal.pone.0015761.

Straalen, N.M., 1996. Critical body concentrations their use in bioindication. Bioindicator systems for soil pollution. Kluwer Academic Publishers, 103 p.

Su, N.Y. \& R. Scheffrahn, 2000. Termites as pests of buildings, p. 437-453. In: Abe T., D.E. Bignell \& M. Higashi (Eds) Termites: Evolution, Sociality, Symbioses, Ecology. Kluwer Academic Publishers. Dordrecht, $187 \mathrm{p}$.

Tripplehorn, C.A. \& N.F. Johnson, 2004. Borror \& DeLong's Introduction to the study of insects. $-7^{\text {th }}$ ed. Belmont, CA: Thompson Brooks/Cole, 864p.

Vargo, E.L. \& C. Husseneder, 2009. Biology of Subterranean Termites: Insights from Molecular Studies of Reticulitermes and Coptotermes. The Annual Review of Entomology, 54: 379-403. DOI: http://dx.doi.org/10.1146/annurev. ento.54.110807.090443.

Vasconcellos, A., A.C.S. Mélo, E.M.V. Segundo \& A.G. Bandeira, 2005. Cupins de duas florestas de restinga do nordeste brasileiro. Iheringia Serie Zoológica, Porto Alegre, 95: 127 - 131. DOI: http://dx.doi.org/10.1590/So07347212005000200003 .

Walter, D.E. \& H. C. Proctor, 1999. Mites: ecology, evolution and behavior. 1. ed. Wallingford: CABI Publishing, $322 \mathrm{p}$.

Wang, C., J.E. Powell \& B. M OC'onnor, 2002. Mites and nematodes associated with three subterranean termite 
species (Isoptera: Rhinotermitidae). Florida Entomologist 85: 499 - 506.

Received in: 19.ix.2015

Zakhvatkin, A.A., 1941. Fauna of U.S.S.R. Arachnoidea 1(1) Accepted in: 04.iii.2016

Tyroglyphoidea (Acari). Inst. Zool. Academy Science.

Moscow, 28: 1-475.

\section{Suggestion citation:}

Silva, A.F., Z.T. Pinto, R.L. Caetano, C. Carriço, T.P. Sato, M. Amorim \& G.S. Gazeta, 2016. Bulb Mites Rhizoglyphus echinopus (Fumouze and Robin) Associated with Subterranean Termite (Isoptera) in Brazil. EntomoBrasilis, 9 (1): 65-68.

Available in: doi:10.12741/ebrasilis.v9i1.553
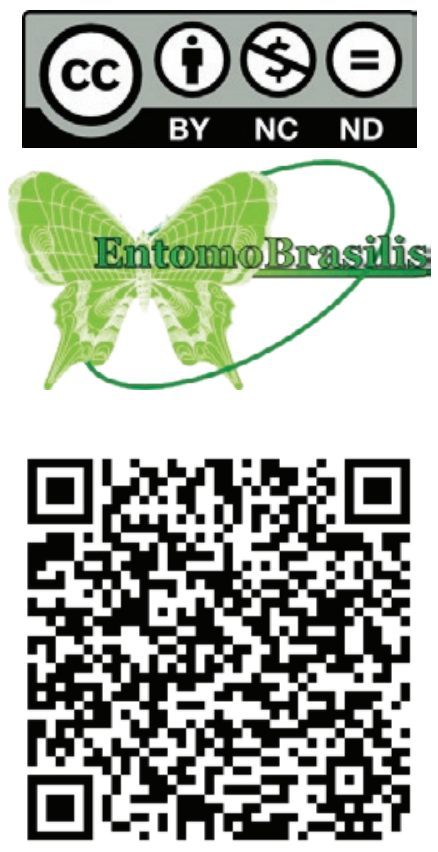